\title{
UNIVERSITYOF
}

FORWARD

THINKING

WESTMINSTER用

WestminsterResearch

http://www.westminster.ac.uk/westminsterresearch

\section{A gaming simulation approach to understanding blue ocean strategy development as a transition from traditional competitive strategy}

Christodoulou, I. and Langley, P.

This is an accepted manuscript of an article published by Taylor \& Francis in the Journal of Strategic Marketing, DOI: 10.1080/0965254X.2019.1597916.

The final definitive version is available online:

https://dx.doi.org/10.1080/0965254X.2019.1597916

(C) 2019 Taylor \& Francis

The WestminsterResearch online digital archive at the University of Westminster aims to make the research output of the University available to a wider audience. Copyright and Moral Rights remain with the authors and/or copyright owners.

Whilst further distribution of specific materials from within this archive is forbidden, you may freely distribute the URL of WestminsterResearch: ((http://westminsterresearch.wmin.ac.uk/)).

In case of abuse or copyright appearing without permission e-mail repository@westminster.ac.uk 


\section{A gaming simulation approach to understanding blue ocean strategy development as a transition from traditional competitive strategy}

\section{Abstract}

Blue Ocean Strategy (BOS) has attracted a resurgence of interest following various market discontinuities, including digital disruption, the growth of the sharing economy and the development of ecosystems. BOS is a combination of value innovation and new markets, driving sustained higher performance through specific marketing activities, but it is difficult to conceive and implement.

We outline five cases that use various transition paths to BOS through white spaces - with product extensions in the existing market. An important part of this transition are blue ocean droplets' which drive profitable growth through the transition and then onto a successful deployment of a blue ocean strategy. Blue ocean droplets drive profitable growth simultaneously increasing volume sales, maintaining/increasing prices and maintaining/decreasing costs.

We then use an inductive qualitative approach in a multi-team gaming simulation to examine drivers of firm performance. Higher than average performance is driven by repositioning in white spaces and execution of the three blue ocean droplets.

Finally, we discuss implications for firms: execute a number of real options to follow one of several transition paths to a full BOS. This approach involves less downside risk than a full BOS approach, but can still be sustainably profitable, while also breaking the traditional value/cost trade-off. 


\section{Keywords}

Blue ocean strategy, strategy, strategic marketing, blue ocean droplets, product innovation, business model innovation, value innovation

\section{Introduction}

In their 25 year review of this journal, Brown, Abduljabbar, Englund \& Treen (2018, p.126) identify a number of conceptual themes which include competitive strategy and innovation. In this empirical paper we explore these two particular themes through a lens of the blue ocean strategy (BOS) paradigm (Kim and Mauborgne, 2017). Their new book follows a resurgence of interest in BOS after various market discontinuities, including digital disruption, the rapid growth of the sharing economy and the development of ecosystems.

The competitive positioning of a firm's product and services is the cornerstone of building a sustainable competitive advantage vs rivals (Porter, 2000). Furthermore, firms can use competitive positioning maps to predict the strategic intent (Hamel and Prahalad, 2005) of rivals and to explore ways to outmaneuver them (D'Aveni, 2007). Hence a close link between the fields of marketing (competitive positioning) and strategy (game theory).

BOS depends on the ability of a firm to offer a unique buyer value in addition to simultaneously reducing its costs. It is inherently connected with strategic marketing concepts as it aims to attract new customers through a unique value proposition. It breaks the 
value/cost trade off (value innovation) and at the same time creates a new market, tapping into an uncontested space towards new customers. By making competition irrelevant the BOS approach is quite different from a differentiation generic strategy (Alam and Tariqul, 2017; Abraham, 2006; Murray, 1988). It enables a company to achieve rapid growth through innovation. Similarly, BOS directly relates to the research of strategic orientation and its connection with business and market performance.

Hence BOS is viewed as a potential solution to a pervasive problem in competitive positioning; a firm may struggle to find uncontested "white spaces" in the multi-dimensional matrix of product attributes (including price). Why? There may be too many competitors that have already established themselves with product extensions and who will aggressively defend their position in "red oceans". Or possibly a failure of marketing communications to persuade consumer segments that a particular positioning is attractive.

Furthermore, research efforts on BOS (Randall, 2015; Ng, Chai, Ismail, Ismail and Khairuzzaman, 2011; David, 2011, Kumar, 2012) emphasize qualitative methodologies with limited samples, whereas most studies on business innovation (Laamanen, 2017) are quantitative. There is a need to more closely align the innovation literature with the BOS approach and close further the methodological gap between these two major strategic concepts.

We believe that one of the first steps is to look into the business model innovation concept and its direct connection to BOS. Then we aim to demonstrate the importance of transitioning through white spaces with some practical advice that we name blue ocean 'droplets'. The term was originally used by Nayar (2010) in his Harvard Business Review paper, where he 
essentially described how some of the BOS tools and actions helped him to be so successful. Nayar, the CEO of HCL Technologies, focused his company's growth by engaging staff in unprecedented ways. In turn, we regard BOS droplets as those key actions that help managers to transition into white spaces, moving from differentiation towards a BOS approach. These actions involve particular strategic marketing activities, including strategic and perceptual repositioning, strategic pricing, uncovering buyer value by identifying hidden opportunities in the buyer's experience cycle and by analysing the buyer utility map.

Kim and Maubornge (2005b) provide the academic community and managers with a set of tools to understand how to develop a BOS. But in practice it is quite difficult to implement a BOS. It takes a major transition from a highly competitive red ocean to identify white spaces and innovate instead of just extending existing product lines. Identifying and winning new customer segments present a great challenge. We suggest that managers will not readily invest time and resources towards a BOS or even business model innovations. Rather, they prefer the safety of their well tested strategic approaches that do not disrupt markets, or the comfort zone of their own inertia. In that respect, we believe that BOS droplets - a few definitive actions - could help them make the transition into blue ocean (new markets/customers and product innovations) that offer two advantages. These could be the perception of safety by not risking their existing strategy, while moving towards a new unique value proposition (innovation) and starting to capture new demand. These BOS droplets were observed in our simulated environment and in the real-world case examples which we analyse further below. In practice BOS droplets include simultaneously increasing buyer value and decreasing costs, together with rapid market growth. Although the strategy might start as a product/value extension, the fact that the value/cost trade-off is broken within a red ocean and also that the market is growing, there is a potential for a BOS. We believe 
that this could be the critical point when managers can change their mindset to pursuing a BOS.

This paper proposes a potential solution to the challenge of developing and implementing a BOS. We propose a set of intermediate steps to develop a BOS via product extensions and transitions, through uncontested white spaces. In other words, implement one or more stages of revised positioning to create a blue ocean.

The next part of the paper presents our critical review of the literature on blue ocean strategy and its antecedents as well as theoretical concepts that directly relate to BOS formulation and implementation. We then continue with our major research questions and methodological notes. Finally, we present our findings and conclusions offering some important insights both for theorists and practitioners.

\section{Background and relevant literature}

In their seminal BOS paper Kim and Mauborgne (2005a, p.2) made a significant statement: 'Industrial organization (IO) economics gave formal expression to the prominent importance of competition to firms' success. IO economics suggests a causal flow from market structure to conduct and performance'. According to this view, the structure of the market is moulding the major actors' behaviour and thus drives the final performance. The particular perspective of environmental determinism leads organisations to decide on a strategic positioning against competition within the industry (Porter, 2008). Following Porter's view, strategic success is dependent upon evaluating what competitors implement and try to do it better; much of it 
being dependent on differentiation marketing actions. Kim and Mauborgne (2017) claim that having a larger market share can be seen as a zero-sum game wherein one company's loss is another company's gain. For this reason, competition seems to become the underlying major factor of strategy development, with the focus on positioning within the competitive space. Although the performance can be high for a company following this particular perspective, it seems that BOS provides another path to high performance. Instead of competing, BOS attempts to avoid direct competition

In doing so, companies should try to identify and capture untapped market space by creating new demand/value. By using the Four Actions Framework and the Strategy Canvas (Kim and Mauborgne, 2017) along with the rest of the BOS tools, companies reshape the market boundaries, mostly from the inside, expanding value while at the same time reducing cost. The last two elements are the key difference to previous classic approaches on competitive strategy. BOS is defined as both offering unique customer value (through value innovation) and at the same time cost reduction. Although, one can argue that this is indeed a hybrid approach according to Porter's generic strategies (Porter, 1998), the catalytic difference is the creation of a new market.

To support their perspective, Kim and Mauborgne (2017) outline a strategy paradox. In a study of 108 new business launches within companies, $86 \%$ were product extensions of existing industry offerings. Only $14 \%$ were aimed at creating new markets or industries. The product extensions represented $62 \%$ of the total revenue and only $39 \%$ of the total profits. In contrast the $14 \%$ creating new markets delivered $38 \%$ of total revenues and a huge $61 \%$ of total profits. The BOS new ventures had much higher performance but were few in number. They had much higher growth and profitability while at the same time reducing costs. BOS 
addresses some of the complexities of high growth firms (Coad, Daunfeldt, Holzl, Johansson, Nightingale, 2014). This is the most fundamental element of BOS as it rejects the tenet of conventional strategy: that a tradeoff exists between value and cost. Agnihotri (2016) also argues that BOS can be executed using product differentiation positioning as an alternative to value innovation. Using examples from online organic food, skincare clinics and custom designed low calorie meals, she illustrates how white spaces in existing strategic groups can be penetrated to target niche segments and increase firm performance.

Morgan and Strong (2003) argue that despite the large amount of research on competitive strategy to the early 2000s, there was a limited connection to firm performance. BOS offers to bridge this gap by claiming a unique market orientation (blue ocean) and superior business performance, following a specific competitive strategy that moves away from red oceans. BOS core elements are about envisioning a new future value proposition (the futurity concept by Morgan and Strong, 2003) and connecting strategic orientation and business performance (as well as riskiness and analysis concepts). Gochhait and Tripathy (2014) argue that a Red Ocean (marketing) strategy promotes guerrilla marketing and brand wars destroying value and decreasing firm performance. Moreover, literature on marketing, especially market orientation (Morgan and Strong, 1997) as well as marketing success (Ambler and Kokkinaki, 1997) and marketing effectiveness (Kotler, 1977) essentially connect the tenants of BOS with strategic marketing. This is evident upon examining the key definitions between marketing and BOS (as competitive strategy) to such an extent that it can be claimed as axiomatic. Looking deeper into the tools and processes of BOS (such as pricing, unique buyer utility, positioning of the product/service and attracting new customers), the connection becomes so strong that it is difficult in many cases to distinguish between strategic (niche) marketing and BOS. 
Following this line of thinking, strategic market creation (Tolin and Caru, 2009; Strong, 2008), is essentially the core concept of BOS offering a fresher perspective on marketing and innovation management. But BOS is not just about breaking the patterns and creating new strategic and marketing paths (Paul and Sánchez-Morcilio, 2018) within national boundaries. Evidence from successful BOS strategies (such as Uber and AirBnB) present companies with the opportunity to expand rapidly internationally. New blue ocean markets are not limited by national borders, especially when accelerated by technologies in a global circular economy where value is hidden in intermediary and interdisciplinary connections. We suggest that BOS strategies can help to transform companies from conservative and predictable into pacemakers (Paul and Sanchez-Morcilio, 2018), offering support to their new model of explaining international growth. Pacemaker companies move at a higher pace even though they are larger (more employees etc.). BOS offers an additional explanation on strategic agility regardless of the size of the original company. Thus bringing a view of (disruptive) innovation (Christensen, Raynor and McDonald, 2015) which needs a smaller size company, together with Paul and Sanchez-Morcilio's (2018) view that larger companies can move fast and scale both products and innovations successfully.

According to this paper, companies can either create greater value for customers at a higher cost or create reasonable value at a lower cost. In other words, strategy is essentially a choice between differentiation and low cost. Many companies are balancing between the extremes of these two options. While creating blue oceans, the evidence shows that successful companies pursue differentiation and low cost simultaneously (Kim and Maubornge, 2004a, p7). It is worth noting that a hybrid approach on generic strategies is different to BOS because having both low cost and differentiation is normally a value/cost trade off. Also with BOS there is 
new market created. Furthermore, the BOS approach is a reconstructionist perspective versus traditional markets as red oceans - a structuralist view (Fogarassy, 2017).

Despite the fact that Porter, in his 2008 paper, argued that the Five Forces Framework is not based upon the zero sum game assumption - it allows for value innovation by strategic repositioning. Still, Kim and Mauborgne emphasize that it is all about the creation of new space. Creating new space, is not a new concept in itself. Hamel and Prahalad in their 1996 book (p.49 - Competing For The Future) advise managers to seek out new market space (Grant, 2008), which they termed white space, in order to "create and dominate emerging opportunities'. On a similar theme, Goedhuys and Sleuwaegen (2010), talk of product innovation that drives unique growth vs just process innovations. Similarly, Moore (2006, 1996 - the Death of competition) explains that industry boundaries are constantly becoming blurry (Valkokari, 2015). On that note, the new leaders do not necessarily focus within traditional industry boundaries and try to reshape them .Today, according to the ecosystems perspective (Peltoniemi and Vuori, 2008; Gossain and Kandiah, 1998) are trying to identify new opportunities in expanding the markets and creating linkages with others. In his Harvard Business Review book, Johnson (2010) analyses the importance of exploitation of white spaces in creating new markets and suggests a methodology, similar to BOS, for creating a unique business model that delivers innovation.

Innovation means creating a new market space. For decades we have known that innovations are not limited to just products and technology. Kim and Mauborgne (2015,2004a) showed that 10 of 13 blue oceans identified in three distinct industries (automobiles, computers, and movie theaters) were created mostly through existing technologies - only three used some 
new technologies (Parvinen, Aspara, Hietanen and Kajalo, 2011). Just one of the 13 was focused on technology pioneering, and the others were focused on value pioneering. In Japan, a technology powerhouse, only $33 \%$ of all patents are actually being used (Hisamitsu, 1999). Research has shown that more than $95 \%$ of patents are unlicensed and $97 \%$ generate no royalties (Landes and Posner, 2003). Another study has shown that only 1\% to 3\% of patents generate a profit for their holders (Myhrvold, 2010). Furthermore, Kim and Mauborgne (2004) showed that incumbents (i.e., among the largest in their industry) created nine of the 13 blue oceans identified in three distinct industries. Start-ups created three and an established player from another industry in which it was among the largest players created just one one. This finding is consistent with many authors who believe that economies of scale remain overwhelmingly important (Hernandez-Villafuerte, Sussex, Robin, Guthrie and Wooding, 2017; Lazonick, 1990) and that a high degree of vertical integration is desirable (Zhang, 2013; Florida and Kenney, 1990).

To understand innovation, we should look into the distinction between product/service innovation and process innovation (Shinour, 2018, Tellis, Prabhu and Chandy 2009, Utterback, 1994; Utterback and Abernathy, 1975). In the former, innovation concerns changes to a firm's offer, which are highly and immediately visible to its clients. In the latter, innovation concerns improvements to the processes (e.g., operations, logistics, and administration), changes that are not immediately visible to the firm's clients. This suggests that product/service innovation entails higher risks for the firm as it potentially has a direct impact on its market positioning and identity (brand value and reputation) in the eyes of its clients. Finally, the degree of change that characterizes a firm's innovation efforts relates to the dichotomy between radical and incremental innovation (McDermott and O'Connor, 2003). With radical innovation, the level of risk stemming from a departure from existing 
organizational routines, as well as the resource commitments that such innovation entails (Sadovnikova, Pujari and Mikhailitchenko, 2016; Veryzer, 1998), is higher compared to incremental innovation.

On another popular study on Yoffie and Cucumano's Judo Strategy (1999; Bergen and Peteraf, 2002) a key principle in highly competitive environments is to 'move rapidly to uncontested ground to avoid head-to-head conflict' (p. 11) by moving into new products that redefine the competitive space, amongst other suggestions. Zott and Amit (2010) conceptualized 'a firm's business model as a system of interdependent activities that transcends the focal firm and spans its boundaries' (p. 216). It is very important to not that these authors seem to perceive innovation both as tangible and as perceptual. This marketing notion is also part of blue ocean strategy since the new market can be a radical repositioning and perceptual innovation to some extent. Historically, there are other research efforts that suggest redefining competition as the Coopetition model by Brandenburger and Nalebuf (1997) along with Game Theory (McCain, 2015; Afuah, 2009). It is argued that the aim of coopetition is to transform the industry from a zero-sum game in which one company gets most profits into a positive sum game where many players can be profitable. Another important perspective on successful adaptation and innovation is the dynamic capabilities framework identifies three components as critical for successful organizational adaptation sensing, seizing and transforming. These seem to be key actions that are later reflected in the marketing and sales processes of the company (Teece, 2007)

BOS seems to offer great insights, in terms of strategic and marketing innovation since it offers a process on conceiving and implementing value innovation. Markides (1997) argues that strategic innovation requires the company to answer three key questions: who will be the 
(new) customers, the how and the what (Gemici and Alpkan, 2015). He is also stating that strategic innovation is usually disruptive and is welcomed by non-customers. Teece (2010), making a step further suggests that most companies create a business model that underlines 'the design or architecture of the value creation, delivery and capture mechanisms' (p. 191) upon which the company is based. Accordingly, business models reflect management's hypothesis about what customers want, how they want it and what they will pay, and how an enterprise can organize to best meet customer needs, and get paid well for doing so. Furthermore, Ryzhkova (2015), on a parallel line, suggests that interacting with customers using online methods is positively associated with high growth firms' likelihood of service innovations, as in the case of Zappos (Demir, Wennberg and McKelvie, 2017). The logic of creating and capturing value can be targeted at a small segment of business customers based on a few key resources, activities, and relationships (Massa, Tucci and Afuah, 2017). There is also usually a strong internal focus and only limited exploration and experimentation (Bogers, Chesbrough and Moedas, 2018; McGrath, 2010).

Kim and Mauborgne (2017) discuss the strategy to create and capture new demand hence tap into uncontested space. They have incorporated most of the previous ideas into one single framework advising companies to avoid direct competition and determine which businesses experience the highest and lowest growth and cash flow. These are classified accordingly with the highest growth potential being pioneers, then to migrators, then to the lowest rung, settlers. These pioneers constitute SBUs of unprecedented value. Interesting examples from recent practice are Fintechs that seem to create their own markets. Their value curve diverges from the competition on a BOS canvas. 
Figure 1 shows how red oceans, white spaces and blue oceans occupy different competitive positions, driven by customers (existing vs new) and product value (stable vs extensions vs innovation). It shows that re-positioning to white spaces is a transition strategy to reach blue oceans and multiple transition paths are possible.

\section{[Figure 1 here]}

Figure 1 The paradox of strategy and three process dimensions of creating a Blue Ocean

BOS starts by 'getting the strategic sequence right' (Kim and Mauborgne, 2017). In this model, potential blue ocean ideas must pass through a sequence of buyer utility, price, cost, and adoption - all essentially are marketing activities. Contrary to classical approaches here it seems more important to first define the buyer utility and price that the customer is willing to pay, and then try to fix the cost structure and profit margin accordingly. Also BOS suggests pricing average to high since the customers identify a unique value and at the same time there is a need to avoid attracting new players too quickly. All these points present BOS as very similar to a business model that creates and fosters innovation.

The capacity to embrace business models that create new value for customers and new wealth for investors is a concept that Christensen (1997) and Hamel (2000) explain. They perceive competition in the contemporary world as no longer between products or services, but between competing innovation regimes. In addition, Tushman and O'Reilly (1997) see the clear identification of opportunity gaps as a starting point for winning through innovation. All 
these authors focus less on competition between companies and products, but instead propose market disruption as a source of entrepreneurial profits.

Finally, apart from connecting BOS with strategic marketing and business model innovation theoretically, BOS does not seem to have been extensively practically investigated (quantitatively with strong market evidence on high growth companies and innovation Demir et al, 2017). Instead as the latter author suggests (pp.445) "The high growth firms differentiation literature emphasizes that high growth is more often reached by way of a single product strategy offered to one market in the entrepreneurial stage and successively emulated in new markets where opportunities are found (Littunen and Tohmo, 2003; O'Regan, Ghobadian and Gallear, 2006; Todd and Taylor, 1993).' Thus, there seems to be a tendency of success via rapid growth by a certain strategic orientation on differentiation rather than a hybrid approach or even a BOS approach.

\section{Blue Ocean Strategy since 2004}

Since Kim and Mauborgne's original paper in 2004, BOS has become a deeply embedded paradigm in strategic thinking and practice. BOS clearly refers to the ability of company to break the traditional value/cost trade-off and acquire the ability to increase buyer value and reduce costs at the same time. The best achievement would be for the company to create its own new market and exploit the untapped demand. Value innovation is achieved by lining up completely the scope of the organisation's value, price and cost activities. It includes, potentially, all the functional and operational activities. In that way, the company draws a brand new value curve, moving away from its direct competition and thus making 
competition irrelevant. Beyond the most popular business cases of Cirque du Soleil, iTunes, Southwest Airlines and Yellow tail, we have witnessed a number of strategic players that follow the previously mentioned actions and pattern of BOS. Some striking examples include Uber and AirBnb. These two companies certainly disrupted traditional markets, creating initially new markets. They created a new unique value for the customers (following the sharing economy trend) by connecting traditional customers with suppliers. Creating a new unique service, capitalising on innovative digital platforms and increasing the usage of existing resources, they managed to drive unprecedented growth. These two were not just adopting a sharing economy approach. Instead, they carefully created new value curves to sustain their profitability and growth for many years, without any direct and significant competition.

We now witness many fintechs not only disrupting traditional financial markets (e.g. mortgages) but essentially creating their own markets. Ant Financial, Oscar, Avant, Atom Bank are among the top 10 fintechs of the world, worth tens of billions of dollars (Miller, 2018). They appear to have followed the BOS approach, avoiding direct competition. Kim and Mauborgne (2017) discuss two interesting examples of BOS implementation - Marvel and Zappos. Marvel managed to turnaround their performance and revitalise their industry (Fox Business, 2009). To turnaround successfully requires both cost reduction and revenue growth. These are possible at the same time by breaking the value/cost trade off via value innovation. Value innovation seems to be more profitable, sustainable and ethical compared to value extension or value extraction, since the latter focuses on rapid cash reduction from the organisation. 
Creating a BOS approach does not come from random actions nor high stakes and big bets. It strategically creates a new market and reduces the potential of failing. Kim and Mauborgne (2017) argue that market (industry) boundaries principally exist in the manager's mind, yet they constrain the traditional strategy development process. By redefining market (industry) boundaries, managers can create and capture blue ocean opportunities, i.e., uncontested market space. It is also important to note that in Marvel's case, culture played a determinant role in transforming the company. Marvel has emphasized the procedural justice and fairness of processes, following the advice of the founders of BOS on implementation. In terms of eliminating, reducing, raising, creating (ERRC), Marvel eliminated high salaries for their executives, reduced the middle offices and the physical infrastructure and lowered salaries for the stars performing the characters. Marvel raised the creativity and emotional attachment to the characters, while creating its own universe along with a unique financing scheme.

Similarly, Zappos - one of the most profitable and fastest growing online shoe selling businesses in the US - adopted a BOS approach. Zappos did not create success by aiming to win over competitors and tap into existing value. Instead it tried to create a new market and capture new demand. To achieve this, Zappos started in a red ocean and then made specific steps into white spaces. Initially, we were puzzled since we saw a blue ocean approach that did not appear to meet strong first mover advantages or even strong entry barriers to other rivals. Its unique service quality, amazing 24/7 customer service and a privately owned efficient delivery system drove value capture and value creation. In particular, Zappos did reduce the various risks and frustrations for purchases of online shoes. Through immediate customer updates, total control of its inventory, orders and warehousing, it aimed for a unique buyer value for its customers. On top of this, it did make purchasing more personalised, with an open policy when it comes to information and a free phone call centre to support 
purchasing. Working hard on site functionality, delivery and customer satisfaction they perfected delivery - fast, free, and in most cases in less than half of the time promised. Additionally the after sales service is extremely convenient along with a unique 365 days return policy. Zappos did not engage the competition aggressively. Although this sounds like a paradoxical statement, Zappos actually helped its customers, in cases of no availability, to find the product they need via their competitors' websites. These steps helped Zappos transit into white spaces and change not only the way it operated, but also the overall market.

Zappos did break the value/cost trade-off by avoiding the price competition with online retailers and trying to imitate the physical store experience. This means that it did try to combine the best of both worlds and reject the worst of both worlds. Increased value did not come with increased costs. Like the Zappos case study there are many examples of firm competition where we may see 'positive sum games' but are not strictly blue ocean because the market is still dominated by the generic strategies or led by differentiation on product extensions. Still, the winning strategies comprise elements of blue ocean 'droplets', namely driving profitable growth through rapid volume sales increases, coupled with maintaining medium/high prices and cost stability or reduction. A vivid example (Kim and Mauborgne, 2015) could be BMW's C1 (a two-wheeled scooter targeted for the affluent customer segment). This was a roofed scooter with a wiper windshield that was extremely safe. Still, all the extra safety and quality elements made it very costly to create and despite the fact that it was a highly differentiated product, it failed to attract many (new) customers. Thus, BMW stopped producing it in 2003, failing to meet its sales targets.

\section{Business Model Innovation and Blue Ocean Strategy}


From Chesbrough's thoughts (2010) on business models and innovation, the BOS approach offers a great combination of a business model that creates and exploits product innovation. This is following Prahalad and Bettis' (1995) earlier notion of a 'dominant logic' of how the firm creates value and then captures value. BOS seems to challenge the dominant logic and to exploit innovation that does not fit existing business models.

BOS actions (new product innovation combined with winning new customers) is gaining attention versus traditional approaches to the development of strategy. Some of the most innovative companies of 2017 (BCG.com, 2018) including AirBnB, Uber, Avant, Ant Financial are only a few of the most recent examples where BOS moves storm traditional market boundaries. Contrary to traditional approaches, like Porter's strategic positioning and generic strategies, blue ocean strategy has the ability to connect different sectors, interlinking different markets and creating interdisciplinary forms of value. One could challenge the actual application of BOS or even the actual nature of the particular perspective claiming that it is another, unique, form of differentiation or an elevated niche marketing approach. Value innovation in positive sum-games seem to be very close to the outcome of a hybrid approach on Porter's generic strategies, applying both cost leadership and differentiation. Extending this particular line of thinking, there are other ways to create value, as Chesbrough (2010) explains on business model innovation. This is often an underrated element of success and there are certain barriers (cognitive and structural) that need to be addressed in order for this value to be exploited (Kim and Mauborgne, 2017). In an empirical study surveying senior managers from a range of large and small organisations in Finland, Aspara, Hietanen and Tikkanen (2010) found that higher profitable growth was generated when a strategic emphasis on business model innovations was combined with business model replications (for 
example in a new geography). The higher performance was evident in comparison to a strategic emphasis focused just on business model innovations.

However, business model innovation is far from straightforward and Chesbrough (2010) does identify different ways of achieving it, for example through experimentation. Reading his extensive review, we were puzzled as to how BOS can be perceived as a business model for innovation. We realised there is a very limited discussion on the particular topic despite the obvious fact that BOS matches the typical description of an innovation business model. It does disrupt the existing market, it creates a new market, it offers a pathway of offering unique buyer value, and calculating the profit and strategic growth of a company.

Further to that, as Zott and Amit (2010) observe on how disruptive innovation causes tension to the existing business model, BOS disrupts traditional markets creating new ones but with limited tension since it aims to make competition irrelevant by avoiding direct confrontation following the same strategic positioning. In one of his latest publications on competitive positioning, Porter (2008) seems to reconfigure his original 1979 model by allowing value innovation and a strategic positioning that moves away from competition. Thus, the debate becomes even more heated with regards to whether a blue ocean strategy is indeed a unique view to strategy development and implementation, or an extension of the existing approaches. Exploring further this particular question could extend our understanding on strategy implementation through BOS as strategic or business model innovation.

We make an effort to unearth hidden differentiated elements of those two perspectives, and reignite a debate that has taken place in the shadows for the past 10 years. The question we pose is rather simple. Is Blue Ocean Strategy (BOS) an approach that comes from following 
traditional game theory and strategic positioning, or is it a pattern that emerges naturally as a very distinctive strategic practice within markets? Thus were Kim and Mauborgne (2004b) the first scholars to witness it and structure a framework around it?

\section{Three cases with transitions through white spaces}

We now outline three additional cases with companies that have executed a transition through white spaces (with product extensions in existing markets) before reaching a full BOS with product innovation and new markets.

\section{Uber}

Uber is a much quoted example of a successful BOS. The product innovation was a web platform that cleared the supply/demand balance between taxi customers and taxi providers using real-time prices. The new customers would previously have travelled in their own cars or by public transport, but were attracted to the new lower Uber price points. However, initially Uber grew the business through a product extension (from traditional phone bookings) - a web platform that matched customers to taxi providers with little or no dynamic pricing - largely a taxi-booking request service. This white space attracted mainly existing taxi customers who would normally use a phone booking service, or hail a taxi in the street. The price points just weren't low enough to attract many new taxi customers.

\section{Nintendo}

Nintendo Wii has also disrupted the traditional video gaming market. At a time when all game consoles were competing with improved graphics, updated joysticks and new games, 
Nintendo came up with Wii. This is a unique gaming console that incorporates the player movement instead of a simple joystick, reducing the cables and complexity of a traditional console. At the same time it was considered a great family entertainment and a way to exercise, thus attracting new customers. Essentially, Nintendo saw the gaming market differently and identified white spaces both into terms of product innovation and new customer segments, combining both into creating a blue ocean. The first steps were to reduce the complexity of the console, improve graphics and simplify gaming - all as product extensions. The particular transition, although disruptive, happened in a very efficient manner for Nintendo boosting its sales and also reducing its operating costs, driven by its simplicity and relatively low promotional effort (Financial Times, 2007).

\section{Fintechs}

Fintech examples that also managed to transit into white spaces include Avant and Atom Bank. In 2012 AvantCredit started offering consumers small personal loans with terms two to five years (Barba, 2015). It had a transparent mode, unique algorithms, machine learning protocols and analytic tools. Along with the traditional consumer data it was able to customise rates, amounts and length at which money can be borrowed.

Some blue ocean droplets for Avant were to efficiently mitigate default risk and fraud by using machine-learning technology, a complete online experience eliminating physical branches, simplification of borrowing process, with the bulk of its employment verification and funding done over the internet (Financial Times, 2017). Essentially streamlining processes and simplifying any bureaucratic bulk for customers it allowed them to first transit into white spaces before the actual innovation take place. Similar to the above business model, Atom bank also became one of UK top online banks offering smartphone banking. 
These two companies both managed to innovate by creating a unique value proposition for their customers but were also quick to move into the white spaces that they identified and created, thus creating a whole new market where banking is quicker, easier, more convenient and more accessible to potentially all customers.

\section{Research design and questions}

Kim and Mauborgne (2017) suggest that migrating from red to blue oceans and fighting in them, has been, and still is a consistent (small scale) practice. The fact that blue and red oceans seem to coexist demands a broader understanding of strategic decision making and implementation, addressing the logic of both oceans. Today, red ocean competition seems to be mostly present compared to blue oceans since most innovations taking place seem to be essentially on product extensions (Ogbogu-Asogwa, Ike , Adeleke, and Ekoja, 2017; David, 2011).

We investigate empirically to what extent BOS, in terms of droplets of strategic actions, actually emerge within a gaming simulation environment. In this particular multi-team simulation of the global retail athletic footwear industry (similar to Zappos), the competing teams could decide on product/service positioning, including the range of models offered, quality of materials, pricing by segment and retailer support. These attributes represent product extensions, rather than radical product innovations, because they are elements that could easily be copied by rivals. Additionally, the white spaces in product/service positioning are not blue ocean opportunities in this simulation, but rather areas where competitive rivalry 
is less intense. However, these empty white spaces are not necessarily going to be profitable because the product/service positioning may not be attractive to existing customers.

Our anecdotal observations from the simulation are that the conduct of high performance teams appears to be inconsistent with traditional generic strategies with regards to positioning on price, product attributes and segment focus. Instead it seems to be more like a hybrid approach with blue ocean droplets - avoiding competition, keeping high prices, reducing costs and growing sales volume - all at the same time. We're looking for the drivers of this higher performance through re-positioning in white spaces with product extensions, as we argue it is an important part of transitioning to a BOS.

Gaming simulations have been used extensively as an empirical theory testing methodology in strategic management and strategic decision-making research (Diegieguez-Barreiro, González-Benito, Galende and Kenji Kondo, 2011). We used a multi-team gaming simulation to explore firm performance over a number of simulated years, together with the strategic decisions that drive that performance.

Our research question is to test the idea (in a strategy gaming simulation environment) that higher performance in a strategy to re-position in white spaces, with product extensions, is driven by the adoption of blue ocean droplets - a combination of increasing sales volume growth, maintaining or increasing prices and maintaining or decreasing costs. Following the real life cases we described previously, where there is limited evidence on how this is happening. We now use a simulated environment to extract a significant amount of data on blue ocean droplets and draw potential linkages on how a company transitions from a red ocean into white spaces and then blue ocean. 


\section{Strategy gaming simulation}

MBA students (both full-time and part-time Exec) in a large business school engaged with a product market simulation (Thompson, Stappenbeck, Reidenbach, Thrasher and Harms, 2017) over a period of six weeks representing six simulated years. This simulation has been used by many undergraduate and postgraduate business/management students worldwide, over a number of years. It is well supported with learning resources - student and instructor manuals, videos, online help etc.

The simulation context is the global athletic footwear industry, with four geographic regions (North America, Europe/Africa, Asia Pacific and Latin America). In each region there are two segments (wholesale and private label), in addition to a global internet segment. Effectively there were nine geography/market segments. An industry comprised 4-10 teams, each with typically 3-5 students. The teams competed with each other, making yearly simulated decisions on pricing and positioning, marketing, operations, capacity, CSR initiatives and debt/equity financing. The market was 'cleared' yearly by the computer simulation, representing consumer choice in each segment and geography.

The simulation represented a 50\% assessment for a module in Strategic Management. It was an engaging activity, over 10 weeks including two practice years, six live years and a further two weeks to prepare and deliver a presentation to their corporate board. The team performance in the simulation (measured using an equally weighted basket of metrics including return on equity, earnings per share, share price, brand image and credit rating) 
counted for $35 \%$ of the assessment ( $35 \%$ of $50 \%=17.5 \%$ of the module assessment). Hence the incentives to perform well were strong. Other assessments included two quizzes, the corporate board presentation, and a team peer review. Teams were well-balanced in terms of age and prior work experience.

Each student team was taking over an existing company in the athletic footwear industry. All existing companies had been operating for a number of years, with identical volume sales, revenues, prices and positioning at the point of student takeover of the management team. The five performance metrics were also identical. In that sense the market was in a dynamic equilibrium at the point of student team takeover.

Each team could position their athletic footwear products on a number of product and service attributes including price, design and materials quality, no. models in the range and retail incentives. This positioning could be varied for each of the nine geography/market segments. Market intelligence reports allowed each team to follow the positioning of competitors, with access to 'public data'.

Figure 2 shows an example two-dimensional positioning 'strategic group map' with seven teams A-G. The size of the circles indicate relative market share. The two axes are "price and S/Q rating' (a value for money metric which combines product net price and style/quality) and 'product line breadth' (effectively the range of athletic shoes models available). Teams can choose to position in a uncompetitive 'white space' but may be followed quickly by competitors. Hence these new positions are closer to product extensions rather than radical product innovations. The 'white spaces' are areas where competitive rivalry is less intense because there are not many, if any, nearby rivals pursuing strategies that compete strongly 
with those that fall into the more wide open white spaces. But all white spaces are not necessarily going to be attractively profitable.

[Figure 2 here]

Figure 2 Wholesale segment - strategic group map (Thompson et al, 2017)

Finally, students competed over six simulated years but were discouraged from adopting an 'end-game' strategy in the final year with the objective of artificially boosting performance metrics, but leaving the company unable to continue beyond the final year. The incentive against doing this was an assessed presentation to a corporate board, where all major actions would be explained.

\section{Results and discussion}

In the next two sections, we first look at team company performance over six simulated years across all 10 different industries, a total of 60 teams (and 240 students). Then we examine more closely an industry in one particular geography/sector.

\section{Performance across all 10 industries}

Table 1 and Figure 3 show the yearly industry average return on equity (ROE) performance for each industry, for each of six years and the overall industry average over six years. ROE is one of five performance metrics (equally weighted in the game performance) but is chosen 
here to illustrate team performance. The ROE performance of all the companies in all the industries was $15.0 \%$ when the student teams takeover and had been at this level for several 'historical' years. Hence $15.0 \%$ is a benchmark performance akin to 'normal' industry returns (at the risk adjusted weighted average cost of capital). We also choose to use the average six year performance (rather than just the performance in the final year six) because it better represents consistency over time. Investors' expectations (in the real world as well as in the simulation) reward longer term consistent performance vs short-term 'blips' of excellence.

The average six year performance varies widely across the 10 industries, from $8.1 \%$ to 20.5\%. The no. teams in each industry vary in size from 3 to 9 players. Industry 9 (shaded light grey in Table 1) with the highest performance (average ROE over six years $=20.5 \%$ ) has only three teams. And the industry 3 (shaded dark grey in Table 1) with the lowest performance (average ROE over six years $=8.1 \%$ ) has seven teams. It appears that industry concentration may be driving performance, but this effect is not consistent across all industries. For example, industries 4 and 5 with nine and four players respectively both achieved an average $\mathrm{ROE}=15.7 \%$, only slightly higher than the $15.0 \%$ benchmark.

We also note the yearly variance in average ROE performance and how it varies widely between industries. This may be driven, in part, by the competitive re-positioning of teams to white spaces within each industry, resulting in volatility in low and high ROE performance. Performance depends on the attractiveness of the white space to customers and the costs involved in re-positioning. Also whether rivals choose to compete in the same white space. We will discuss this more fully later on by looking closely at a particular industry's ROE performance over time. 
[Table 1 here]

[Figure 3 here]

Figure 3 Industries 1-10 - Average ROE\% for years 0-6

\section{One industry detailed performance}

Industry 10 has seven teams and a total of 32 students. Table 2 shows average performance over six years for ROE, revenue and net profit in $\$ \mathrm{~m}$, and relative to the competition, for each of the seven teams A-G in Industry 10.

ROE performance is similar directionally to both revenue share and net profit share. For example high performing teams $\mathrm{A}, \mathrm{C}$ and $\mathrm{E}$ are relatively high on all three metrics. Conversely, low performing teams B and $\mathrm{F}$ are relatively low on all three metrics.

Thus the ROE performance is driven by both revenue (price $\mathrm{x}$ sales volume) and profit (revenue - costs). High performing teams are performing well on some combination of price, sales volume and costs - all elements of blue ocean droplets - and we aim to understand these three elements in more depth. 


\section{[Table 2 here]}

Now we look in Table 3 at the ROE performance by year for each team A-G in industry 10. Team ROE performance can vary widely by year. The average ROE\% consistency metric shows the average (absolute) variance over 6 years. For example, team $\mathrm{C}$ has a high average $\mathrm{ROE} \%$ of $21.3 \%$ and is highly consistent with average absolute variance of $2.6 \%$. But team E also has a high average ROE\% of $20.7 \%$ with a low consistency of $5.2 \%$.These high and low volatilities in performance are in part explained by the teams' strategies to position in white spaces. A re-positioning to a white space with few rivals may initially incur large marketing (and other operational costs). Coupled with weak demand from consumers not attracted to the new product value proposition can create downward pressure on profits and ROE performance. Hence the re-positioning to white space strategy appears to be unsuccessful in terms of short-term performance. But this situation may turnaround as marketing spend and word-of-mouth network effects becomes more effective, creating upward pressure on improved ROE performance over the next year or two. But in turn this increase in ROE performance may be eliminated as competitor teams enter the new position to compete for excess profits. Hence driving further volatility in the ROE performance. So the success of a repositioning to white space strategy depends on multiple elements, but initially careful spending on additional marketing and operational costs is important.

In this gaming simulation, product innovation is not possible hence a full BOS cannot be executed. This means that within the particular simulated environment there is no way that a company can create its own unique market via a new disruptive product or service. The existing companies have to fight against each other to win market share and profits. However, 
it is not a zero sum game because the market is expanding and some competitors can be profitable, through re-positioning via product extensions to a white space. But, as we said above, the market demand is growing between 5\%-11\% per year, varying by geography and segment. So there are new customers in the existing market who are attracted to existing products or product extensions in white spaces. We want to understand if there is evidence of higher than average performance while re-positioning with product extensions? This particular simultaneous combination is what we call BOS droplets and shows potential for a BOS execution.

\section{[Table 3 here]}

Now we look at team performance in the industry 10 North American Wholesale market segment. This represents $22.4 \%$ of industry volume sales, $19.2 \%$ of industry revenues and $14.9 \%$ of industry operating profits.

Table 4 shows how company operating profit performance relative to the competition compares to three other metrics - retail price relative to competitors (company price / industry average price), operating costs as \%revenue relative to competitors (company operating costs as \%revenue / industry operating costs as \%revenue) and sales volume growth relative to competitors (company sales volume growth / industry sales volume growth). All metrics are averages over six years.

Team $\mathrm{C}$ shows operating profit $13 \%$ above competitors (industry average), together with a wholesale price $13 \%$ above competitors, operating costs $3 \%$ below competitors, and annual volume sales growth $262 \%$ above competitors. 
Team C's higher than average operating profit performance is driven by a strategy of 'profitable growth' which pushes sales volume growth (much) higher, whilst keeping wholesale prices high and operating costs stable. This strategy to drive profitable growth is based on positioning in a white space with a relatively high shoe price, coupled with a wide range of models and superior quality designs and materials. This positioning is supported by marketing through advertising, retailer service support, promotions and celebrities. But advertising costs fall between years 1 to 6 from $13.9 \%$ of revenue to $12.5 \%$. A shift from cash spend to reputation and word-of-mouth effects through brand building and other reinforcing reputation growth mechanisms. In fact, between year 1 to 6 , overall operating costs fall from $82.4 \%$ of revenue to $78.8 \%$. Rivals do not re-position to compete in this new white space with team $\mathrm{C}$ until the final year 6 , likely deterred by higher price and strong brand reputation already established.

A similar story for team E. They show operating profit $95 \%$ above competitors (industry average), together with a wholesale price $8 \%$ above competitors, operating costs $3 \%$ below competitors, and annual volume sales growth $81 \%$ above competitors. Both teams $\mathrm{C}$ and $\mathrm{E}$ have followed blue ocean droplets actions - driving volume sales growth, maintaining high prices and maintaining cost stability. They have re-positioned to white spaces through product extensions, driving sales growth without overspending on new product manufacturing or marketing costs.

However, relatively low performing teams $\mathrm{D}$ and $\mathrm{F}$ underperform operating profit relative to competitors, achieving only $87 \%$ and $47 \%$ of the average respectively. Their prices are lower, sales growth is lower and costs are higher, all relative to the competition. In contrary to the 
higher than average performing teams $\mathrm{C}$ and $\mathrm{E}$, they do not follow any of the three blue ocean droplets actions.

[Table 4 here] 
In summary, the particular findings reveal that two high performance simulated companies do indeed implement the blue ocean droplets, whereas the two poor performing companies do not. This is consistent with what we theorized. There seems to be a pattern from practitioners moving towards white spaces, managing both growth and cost at the same time. If this is indeed the case for many rapidly developing markets then in the following years we should expect a large and diverse set of actions using the BOS droplets. And then many more fully developed blue ocean strategies will emerge to disrupt the existing markets. We believe that a great example of this trend is already happening is the fintech companies. Enabled by technology and not just using BOS droplets, but completely disrupting traditional financial markets to create new ones. We now discuss why these findings are important for theorists and practitioners in terms of specific implications and contributions.

\section{Conclusions}

Our starting point was the debate on whether BOS is indeed a radical approach to strategy development and implementation, or an extension of the existing approaches. Is BOS an approach that comes from following traditional strategic marketing, competitive positioning and game theory, or is it a pattern that emerges naturally as a very distinctive strategic action within markets? We believe, according to the BOS droplets observed emerging both in a simulated environment and in real markets, that there is a pattern of strategic actions emerging. Practitioners likely prefer to avoid direct strategic confrontation and instead focus 
on finding a way to reposition themselves to then create a BOS innovation at a later stage. More specifically, strategic positioning as explained by Porter (2008) is not sufficient to explain these disruptive innovations and the new markets that emerge.

Although well-known BOS success stories (including Uber, Airbnb, Cirque du Soleil, Zappos) report high performance outcomes (and driving sustainable competitive advantage), there really aren't too many of them to report. Apparently, a transition from red ocean to blue ocean directly is quite difficult to achieve (Abraham, 2006). This is because there are many difficulties to overcome in first creating new markets, but then even more challenges to scale them (Alam and Tariqul, 2017).

There are a number of cases (including Uber, Nintendo, Fintechs) which first transition through white spaces, with product extensions and existing customers, prior to reaching a full BOS (with product innovation and new markets and customers). This transition through white spaces is bedevilled by performance challenges - potential higher marketing and production costs, rivals joining the white space and competing away the profits, and customers who are not attracted to the new value proposition. How can a firm make the transition profitable? We suggest the firm should build a re-positioning strategy which includes blue ocean droplets. Specifically, driving volume sales growth, keeping prices stable/higher, and keeping costs stable/lower. These three actions drive rapid profitable growth. Once again, we need to emphasize that performing these three actions simultaneously is the toughest element to implement but doing it successfully is an indication that there is a full BOS potential. 
We tested this idea further using a strategy gaming simulation, based on traditional product positioning, with white spaces and product extensions (but without blue oceans and product innovations). We observe that some teams are able to achieve higher than average performance using a re-positioning strategy with product extensions and existing markets. We also observe in the particular simulation results that the blue ocean droplets were executed for the specific high performing teams, but in contrast were completely absent for the specific poor performing teams. We consider these to be important findings since they follow the real life cases that we discussed previously. We have defined a new set of strategic actions, the blue ocean droplets, which lie in between a traditional hybrid approach and a full BOS. Our results add to the extant literature which has described BOS as a discrete step from enhanced differentiation. In contrast, we see it as a continuous process initially with product extensions and existing customers, incorporating blue ocean droplets, which will eventually morph to a full BOS with product innovations and new markets. The particular activities involve conceptual and strategic repositioning, strategic pricing, uncovering buyer utility, exploring the customer experience cycle further and value innovation.

\section{Limitations}

First there is the question of the validity of results from a student-based gaming simulation, when used to make inferences about real-world managers' execution of BOS. The MBA students aged 25-50 had varied management experience by role, sector and organization size. Many students would have similar profiles to real-world managers executing BOS. There were strong incentives to perform well, through contributions to grading. Rivalry was intense because weekly rankings were transparent to all teams. However, it is likely that participants 
in gaming simulations take more risks than in the real-world, because the penalties for failing are not really very severe (i.e., getting a lower grade than expected). Furthermore, a realworld year of strategy decisions involving multiple briefing papers, meetings, discussion and reflection is compressed into just one week and typically comprises just two to four hours of activity.

We chose just one simulated geography/segment in just one simulated industry to observe emerging blue ocean droplets. A qualitative exploratory study approach. But our results cannot be generalised to explain superior performances across all the simulated industries and geographies. There may be multiple drivers of superior performance that are not related to the execution of blue ocean droplets. We did not test for that due to resource and time constraints.

\section{Directions and proposals for future research}

A future research project could look at simulated superior performance over a larger dataset, using quantitative methodologies. This approach could test the proposition that superior performance is driven by the application of the three blue ocean droplets. We could also test certain hypotheses that explore whether only one or two of the three blue ocean droplets drive superior performance. Furthermore, future research should test for moderating and mediating effects when transitioning through white spaces since there could be some hidden variables affecting the formation of blue ocean strategy that might not relate to what has been identified so far. This would be an impactful finding because of the potentially much lower implementation costs, clear managerial guidelines for practitioners in increasing profits and growth, but also a fresh insight into a more practical investigation of traditional strategy and 
marketing compared to BOS. Such investigations, like this one, will aim to link the traditional strategic approaches to BOS, formulating a unified model of business strategy, marketing and innovation.

Following this line of thinking, future work could examine real-world cases using primary data to understand first the timing and then the processes needed to develop white space transitions. How does the full BOS emerge from the transition? What transition paths are the most successful? What are the implementation challenges in managing these transitions and how might they best be overcome?

Re-positioning in white spaces could be seen as exercising a real option to test a product extension with new or existing customers. Real option theory (ROT, Smit and Trigeorgis, 2012) could help us to understand the effectiveness of these various transition paths. ROT values the uncertainty around investments in product extensions. The uncertainty includes competitor moves, existing or new customer demand changes in response to macroenvironment trends, and technological opportunities and threats. The research agenda would value the real options of pursuing a number of different strategies to transition through white spaces. The methodology should involve real-world case studies or simulated markets as well as large sample quantitative data..

\section{Implications for managers}


A possible trajectory to full BOS is to first re-position in a white space using existing product extensions and in existing markets. This involves less downside risk than a full BOS approach, but can still be sustainably profitable. Effectively a firm can exercise a number of real options to follow one of several paths to a full BOS. Following the blue ocean droplets actions may help drive higher performance on these white space trajectories to BOS, achieving profitable growth while breaking the traditional value/cost trade-off.

Another implication of this study is the inability of current simulations to capture and support the development of a BOS approach, allowing for a new market to emerge through new product innovation. Such a tool would be a powerful tool for managers and educators. Apart from demonstrating to the managers the options to grow we also offer a set of advices and actions on how to lower implementation costs along with safely identifying opportunities to innovate. These are managerial guidelines for practitioners both for large companies but also for SMEs. Similarly, market expansion and business model innovation is not restricted by geographical scope thus we aim to support managers both in their local and international efforts.

Finally, future efforts should be made to update existing and create new business simulations to train managers and students for BOS. This will support the learning of innovative business thinking and its application early on, addressing the issue of conformity of graduate students lacking creative thinking. We hope that the present study will generate interest from scholars and practitioners, thus stimulating a fresh dialogue on strategic marketing and innovation. 


\section{Disclosure statement}

No potential conflict of interest was reported by the authors. 


\section{References}

Abraham, S. (2006). Blue oceans, temporary monopolies, and lessons from practice, Strategy \& Leadership, Vol. 34 Issue: 5, pp.52-57.

Afuah, A. (2009). Strategic innovation: New Game Strategies for Competitive Advantage. New York: Routledge.

Afuah, A. (2014). Business model innovation: Concepts, analysis, and cases. (1st Ed) Publisher: Routledge

Agnihotri, A. (2016). Extending boundaries of Blue Ocean Strategy, Journal of Strategic Marketing, 24:6, 519-528

Alam, S., Tariqul, I.M. (2017). Impact of Blue Ocean Strategy on Organizational Performance: A Literature Review Toward Implementation Logic (January 1). IOSR Journal of Business and Management, Vol. 19,

Amit , R. and Zott , C. (2012). Creating Value Through Business Model Innovation. MIT Sloan Management Review, vol. 53, 2012, no. 3, pp. 41-49.

Aspara, J., Hietanen, J., Tikkanen, H. (2010). Business model innovation vs replication: financial performance implications of strategic emphases, Journal of Strategic Marketing, $18: 1,39-56$ 
Barba, R. (2015). 'AvantCredit Rebrands as “Avant”, Acquires ReadyForZero'. Tech.Co (formerly Tech Cocktail). Tech.com [online article].Available at: https://tech.co/news/avantcredit-rebrands-as-avant-acquires-readyforzero-2015-03 [Accessed 28 January 2019].

BCG.COM (2018). Most Innovative Companies 2018: Innovators Go All In on Digital. [online] Available at: https://www.bcg.com/publications/collections/most-innovativecompanies-2018.aspx [Accessed 28 January 2019].

Bergen, M. and Peteraf, M. (2002). Competitor identification and competitor analysis: a broad-based managerial approach. Managerial and Decision Economics, 23(4-5), pp.157169.

Bloomberg Businessweek (2010). Tony Hsieh: Redefining Zappos' Business Model. [online] Available at: https://www.bloomberg.com/news/articles/2010-05-27/tony-hsieh-redefiningzappos-business-model [Accessed 28 January 2019]].

Bogers, M , Chesbrough, H., Moedas, C., (2018). Open Innovation: Research, Practices, and Policies, California Management Review, Vol 60, Issue 2, pp. 5 - 16

Brown, T., Abduljabbar, M., Englund, S. and Treen, E. (2018). Twenty-five years and counting: an analysis of the Journal of Strategic Marketing, Journal of Strategic Marketing, $26: 2,125-139$ 
Chesbrough, H. (2010). Business Model Innovation: Opportunities and Barriers. Long Range Planning, vol. 43.

Christensen, C.M. (1997). The Innovator's Dilemma: When New Technologies Cause Great Firms to Fail. Harvard Business School Press, Boston.

Christensen, C. M., Raynor, M. E., \& McDonald, R. (2015). What is disruptive innovation. Harvard Business Review, 93(12), 44-53.

Coad, A., Daunfeldt, S.O., Holzl, W., Johansson, D., Nightingale, P. (2014). High-growth € firms: introduction to the special section. Industrial and Corporate Change, Volume 23, Number 1, pp. 91-112

D'Aveni, R.A., (2007). Mapping your competitive position. Harvard business review, 85(11), pp. $110-20$

David M.N. (2011). Understanding the Blue Oceans in the 21st century, European Journal of Business and Management. 3(4), 133-145

Demir, R. Wennberg, K., McKelvie A. (2017). The Strategic Management of High-Growth Firms: A Review and Theoretical Conceptualization, Long Range Planning, Volume 50, Issue 4, Pages 431-456,

Diegieguez-Barreiro, J.H., González-Benito, J., Galende, J. Kenji Kondo, E. (2011). Developments in Business Simulation and Experiential Learning, Volume 38. 
Fogarassy, C., Horvath, B. \& Magda, R. (2018). Business Model Innovation as a Tool to Establish Corporate Sustainability. Visegrad Journal on Bioeconomy and Sustainable Development, 6(2), pp. 50-58.

Financial Times (2017). New-generation UK banks challenge with technology [online] Available at: https://www.ft.com/content/716cb86c-002d-11e7-8d8e-a5e3738f9ae4 [Accessed 28 Jan. 2019].

Financial Times (2007). Nintendo's Wii outsells rival consoles [online] Available at: https://www.ft.com/content/58c00a80-c1a9-11db-ae23-000b5df10621 [Accessed 28 January 2019]

Fox Business (2009). Disney Completes Marvel Acquisition [online] Available at :https://www.foxbusiness.com/story/markets/industries/media/disney-completes-marvelacquisition [Accessed 28 January 2019]

Gemici, E. and Alpkan, L. (2015). An Application of Disruptive Innovation Theory to Create a Competitive Strategy in Turkish Air Transportation Industry. Procedia - Social and Behavioral Sciences, 207, pp.797-806.

Goedhuys, M., Sleuwaegen, L. (2010). High-growth entrepreneurial firms in Africa: a quantile regression approach. Small Business Economics 34, 31e51. 
Grant, R. (2008). The Future of Management: Where is Gary Hamel Leading Us? Long Range Planning, 41(5), pp.469-482.

Hamel, G. (2000). Leading the Revolution. Harvard Business School Press, Boston

Hamel, G, Prahalad, C.K. (1996). Competing for the Future. Boston, Mass: Harvard Business School Press,

Hamel, G. and Prahalad, C.K., (2005). Strategic intent. Harvard business review, 83(7), pp.148-161.

Hernandez-Villafuerte, K., Sussex, J., Robin, E., Guthrie, S. and Wooding, S., (2017). Economies of scale and scope in publicly funded biomedical and health research: evidence from the literature. Health research policy and systems, 15(1), p.3

Hisamitsu, A. (1999). Intellectual Property Policies for the Twenty-first Century: The Japanese Experience in Wealth Creation. WIPO, Geneva

Johnson, M. W. (2010). Seizing the white space: Business model innovation for growth and renewal. Harvard Business Press

Kandiah, G. , Gossain, S. (1998). Reinventing value: The new business ecosystem, Strategy \& Leadership, Vol. 26 Issue: 5, pp.28-33, 
Kim, W. Chan; Mauborgne, R. (2004a). Blue Ocean Strategy. Harvard Business Review, September

Kim, W. Chan; Mauborgne, R. (2004b). Value Innovation: The Strategic Logic of High Growth. Harvard Business Review, July

Kim, W. C. , Mauborgne , R. (2005a). Blue Ocean Strategy: How to Create Uncontested Market Space and Make Competition Irrelevant. Harvard Business Review Press, 2005, pp. 256.

Kim, W. Chan; Mauborgne, R. (2005b). Blue Ocean Strategy: From Theory to Practice. California Management Review. 47 (3): 105-121.

Kim, W. Chan; Mauborgne, R . (2015). Red Ocean Traps. Harvard Business Review, March

Kim, W. C., Mauborgne, R. (2017). Blue Ocean Shift : Beyond Competing - Proven Steps to Inspire Confidence and Seize New Growth. London, Pan MacMillan.

Kumar, A. S. (2012). Blue Ocean Strategy. TechnoparkToday.com. Retrieved 29 Jan 2019.

Landes, W., Posner, R., (2003). The Economic Structure of Intellectual Property Law. Belknap Press, Cambridge.

Lazonick, W. (1990). Competitive Advantage on the Shop Floor. Harvard University Press, Cambridge, MA 
Littunen, H., Tohmo, T. (2003). The high growth in new metal-based manufacturing and business service firms in Finland. Small Business Economics. Vol. 21

Markides, C. (1997). Strategic innovation. Sloan Management Review, 38, 9-24.

Massa, L., Tucci, C. and Afuah, A. (2017). A Critical Assessment of Business Model Research. Academy of Management Annals, 11(1), 73-104.

McCain, R. (2015). Game Theory and Public Policy, SECOND EDITION. Cheltenham, Gloucestershire: Edward Elgar Publishing.

McDermott, C. M. and O'Connor, G. C. (2003). Managing radical innovation: an overview of emergent strategy issues. Journal of Product Innovation Management, 19: 424-438.

McGrath, R.G. (2010). Business Models: A Discovery Driven Approach, Long Range Planning, 43/2-3, 247-261.

Miller, K. (2017). Fintech 100 announced. [online] KPMG. Available at: https://home.kpmg.com/xx/en/home/media/press-releases/2017/11/the-fintech-100announcing-the-worlds-leading-fintech-innovators-for-2017.html [Accessed 28 January 2019]].

Moore, J. F. (1996). The Death of Competition: Leadership and Strategy in the Age of Business Ecosystems. New York: Harper Business. 
Moore, J. (2006). Business Ecosystems and the View from the Firm. The Antitrust Bulletin, 51(1), pp.31-75.

Morgan, R.E., and Strong C.A. (2003). "Business performance and dimensions of strategic orientation." Journal of Business research 56.3 : 163-176.

Murray A.I. (1988). A Contingency View of Porter's 'Generic Strategies', Academy of Management Review 13:3, 390-400

Myhrvold, N. (2010). The big idea: funding eureka! Harvard Business Review, 88, 40-50.

Nalebuff, B.J. , Brandenburger, A.M. (1997). Co-opetition: Competitive and cooperative business strategies for the digital economy, Strategy \& Leadership, Vol. 25 Issue: 6, pp.28-33

Nayar, V. (2010). How I Did It: A Maverick CEO Explains How He Persuaded His Team to Leap into the Future. Harvard Business Review, June

Ng, A., Chai, L., Ismail, D., Ismail, W., Khairuzzaman, W. (2011). Blue Ocean Strategy: A Preliminary Literature Review and Research Questions Arising. Australian Journal of Basic and Applied Sciences. 5.86 - 91.

O'Regan, N., Ghobadian, A., Gallear, D. (2006). In search of the drivers of high growth in manufacturing SMEs. Technovation 26, 30e41. 
Ogbogu-Asogwa, O., Ike R.N., Adeleke, B.S, Ekoja, G.O. (2017). Impact of Blue Ocean Strategy on Value Innovation: A Study of Selected Firms' in FMCG and Telecommunications Sectors in South-West Nigeria. International Journal of Scientific \& Engineering Research, Volume 8, Issue 10, October

Parvinen, P., Aspara, J., Hietanen, J. and Kajalo, S., (2011). Awareness, action and contextspecificity of blue ocean practices in sales management. Management Decision, 49(8), 12181234

Paul, J., and Sánchez-Morcilio, R. (2018). Toward A new model for firm internationalization: Conservative, predictable, and pacemaker companies and markets. Canadian Journal of Administrative Sciences/Revue Canadienne des Sciences de l'Administration.

Peltoniemi, M, Vuori, E. (2008). Business Ecosystem as the New Approach to Complex Adaptive Business Environments. Proceedings of EBusiness Research Forum.

Porter, M. E. (1985). How information gives you competitive advantage. Harvard Business Review, vol. 63, 1985, no. 4, pp. 149-160.

Porter M.E. (1998). On Competition, Harvard Business School Press, September Porter M.E. (2000). What Is Strategy? Harvard Business Review. February

Porter, M. E. (2008). The five competitive forces that shape strategy. Harvard Business Review, 86(1), January, 57-71 
Randall, R. (2015). W. Chan Kim and Renée Mauborgne dispel blue ocean myths, Strategy \& Leadership, Vol. 43 Issue: 2, pp.11-14,

Ryzhkova, N. (2015). Does online collaboration with customers drive innovation performance? Journal of Service Theory and Practice 25, 327e347.

Sadovnikova, A., Pujari, A. and Mikhailitchenko, A. (2016). Radical innovation in strategic partnerships: A framework for analysis. Journal of Business Research, 69(5), pp.1829-1833.

Smit, H.T.J., Trigeorgis, L. (2012). Strategic investment: Real options and games, Princeton University Press.

Strong, C. (2008). BOOK REVIEW, Journal of Strategic Marketing, 16:4, 355-357,

Teece, D. J. (2007). Explicating dynamic capabilities: the nature and microfoundations of (sustainable) enterprise performance. Strategic Management Journal, 28: 1319-1350.

Teece, D.J., 2010. Business models, business strategy and innovation. Long range planning, 43(2-3), pp.172-194.

Tellis, G., Prabhu, J. and Chandy, R. (2009). Radical Innovation Across Nations: The Preeminence of Corporate Culture. Journal of Marketing, 73(1), pp.3-23. 
Thompson, A.A., Stappenbeck, G.A., Reidenbach, M.A., Thrasher, I.F., Harms, C.C. (2017). BSG Business Strategy Game, McGraw-Hill Education, Inc.,

Todd, A., \& Taylor, B. (1993). The baby sharks: strategies of Britain's supergrowth companies. Long range planning, 26(2), 69-77.

Tushman, M.L., O’Reilly, C.A. (1997). Winning Through Innovation. Harvard Business Scholl Press, Boston, MA.

Utterback, J.M. (1994). Mastering the Dynamics of Innovation. Harvard Business School Press

Utterback, J.M. and Abernathy, W. (1975). A Dynamic Model of Process and Product Innovation, Omega, (Vol. 3/6, pp. 639-656)

Valkokari, K. (2015). Business, Innovation, and Knowledge Ecosystems: How They Differ and How to Survive and Thrive within Them. Technology Innovation Management Review, $5(8)$, pp.17-24.

Veryzer, R. W. (1998). Discontinuous Innovation and the New Product Development Process. Journal of Product Innovation Management, 15: 304-321.

Yoffie, D. B. and Cusumano, M.A. (1999). Judo Strategy: The Competitive Dynamics of Internet Time, Harvard Business Review, January-February 
Zhang, D. (2013). The Revival of Vertical Integration: Strategic Choice and Performance Influences. Journal of Management and Strategy, 4(1).

Zott, C., Amit, R. (2010). Business model design: an activity system perspective. Long Range Planning. 43 (2010) 216-226 
Table 1

Industries 1-10

Average ROE\% for years 1-6, average over six years and average deviation from benchmark ROE $15 \%$

\begin{tabular}{|c|c|c|c|c|c|c|c|c|c|}
\hline Industry & $\begin{array}{l}\text { No. } \\
\text { teams }\end{array}$ & $\begin{array}{l}\text { ROE } \\
\%\end{array}$ & $\begin{array}{l}\text { ROE } \\
\%\end{array}$ & $\begin{array}{l}\text { ROE } \\
\%\end{array}$ & $\begin{array}{l}\text { ROE } \\
\%\end{array}$ & $\begin{array}{l}\text { ROE } \\
\%\end{array}$ & $\begin{array}{l}\text { ROE } \\
\%\end{array}$ & $\begin{array}{l}\text { Average } \\
\text { over }\end{array}$ & $\begin{array}{l}\text { Deviation } \\
\text { from }\end{array}$ \\
\hline & & year1 & year2 & year3 & year4 & year5 & year6 & 6 years & $\begin{array}{l}\text { benchmark } \\
\text { ROE }=15 \%\end{array}$ \\
\hline 1 & 5 & 19.2 & 21.3 & 17.7 & 15.5 & 13.4 & 15.4 & 17.1 & 2.1 \\
\hline 2 & 8 & 18.0 & 17.4 & 13.8 & 12.6 & 15.1 & 11.8 & 14.8 & -0.2 \\
\hline 3 & 7 & 12.7 & 9.4 & 2.4 & 3.7 & 5.8 & 14.5 & 8.1 & -6.9 \\
\hline 4 & 9 & 10.5 & 10.7 & 19.6 & 16.5 & 16.6 & 20.1 & 15.7 & 0.7 \\
\hline 5 & 4 & 19.7 & 20.2 & 17.0 & 12.8 & 12.3 & 12.5 & 15.7 & 0.7 \\
\hline 6 & 6 & 17.0 & 9.6 & 11.5 & 15.7 & 17.3 & 18.5 & 14.9 & -0.1 \\
\hline 7 & 5 & 16.0 & 16.6 & 13.4 & 17.5 & 16.8 & 17.1 & 16.2 & 1.2 \\
\hline 8 & 6 & 16.4 & 11.8 & 3.5 & 4.2 & 18.2 & 17.5 & 11.9 & -3.1 \\
\hline 9 & 3 & 19.9 & 20.0 & 19.8 & 19.6 & 23.8 & 19.7 & 20.5 & 5.5 \\
\hline 10 & 7 & 17.2 & 19.2 & 14.8 & 15.2 & 17.3 & 15.3 & 16.5 & 1.5 \\
\hline
\end{tabular}


Table 2 Industry 10, teams A-G, all segments - performance metrics ROE\%, revenue share\% and net profit share\%, averaged over six years and relative to competition

\begin{tabular}{|c|c|c|c|c|c|c|}
\hline & ROE \% & ROE \% & $\begin{array}{l}\text { Revenue } \\
\text { share \% }\end{array}$ & Revenue share \% & $\begin{array}{l}\text { net profit share } \\
\%\end{array}$ & $\begin{array}{l}\text { net profit share } \\
\%\end{array}$ \\
\hline & & $\begin{array}{l}\text { relative to } \\
\text { competition }\end{array}$ & & $\begin{array}{l}\text { relative to } \\
\text { competition }\end{array}$ & & $\begin{array}{l}\text { relative to } \\
\text { competition }\end{array}$ \\
\hline Team & average 6 yrs & average 6 yrs & average 6 yrs & average 6 yrs & average 6 yrs & average 6 yrs \\
\hline $\bar{A}$ & 19.0 & 1.1 & $17.0 \%$ & 1.2 & $20.2 \%$ & 1.4 \\
\hline B & 13.2 & 0.8 & $13.5 \%$ & 0.9 & $11.5 \%$ & 0.8 \\
\hline $\mathrm{C}$ & 21.3 & 1.3 & $16.4 \%$ & 1.1 & $19.8 \%$ & 1.4 \\
\hline $\mathrm{D}$ & 15.6 & 0.9 & $12.7 \%$ & 0.9 & $12.7 \%$ & 0.9 \\
\hline $\mathrm{E}$ & 20.7 & 1.3 & $16.2 \%$ & 1.1 & $18.8 \%$ & 1.3 \\
\hline $\bar{F}$ & 10.2 & 0.6 & $10.2 \%$ & 0.7 & $6.7 \%$ & 0.5 \\
\hline $\mathrm{G}$ & 15.7 & 1.0 & $14.0 \%$ & 1.0 & $10.3 \%$ & 0.7 \\
\hline
\end{tabular}

Note: define 'relative to competition' as (team metric / average metric for all teams) 
Table 3

Industry 10 , teams A-G, all segments - ROE\% for years 1-6, six year average and average ROE consistency over six years

\begin{tabular}{|c|c|c|c|c|c|c|c|c|}
\hline Team & $\begin{array}{l}\text { ROE } \\
\%\end{array}$ & ROE\% & ROE\% & ROE\% & $\begin{array}{l}\text { ROE } \\
\%\end{array}$ & ROE\% & $\begin{array}{l}\text { Average } \\
\text { ROE\% } \\
\text { over }\end{array}$ & $\begin{array}{l}\text { average } \\
\text { ROE\% } \\
\text { consistency } \\
\text { over }\end{array}$ \\
\hline & year1 & year2 & year3 & year4 & year5 & year6 & 6 years & 6 years \\
\hline A & 20.9 & 22.9 & 14.5 & 16.5 & 18.6 & 20.5 & 19.0 & 3.7 \\
\hline B & 7.6 & 13.6 & 15.0 & 14.2 & 16.8 & 12.2 & 13.2 & 3.8 \\
\hline $\mathrm{C}$ & 23.0 & 20.5 & 20.6 & 21.1 & 22.7 & 19.6 & 21.3 & 2.6 \\
\hline D & 15.6 & 15.6 & 13.8 & 14.6 & 17.3 & 16.7 & 15.6 & 1.1 \\
\hline $\mathrm{E}$ & 26.4 & 27.8 & 16.1 & 17.3 & 19.9 & 16.9 & 20.7 & 5.2 \\
\hline $\mathrm{F}$ & 9.3 & 15.4 & 8.1 & 8.8 & 9.9 & 9.5 & 10.2 & 3.6 \\
\hline G & 17.9 & 18.9 & 15.8 & 13.9 & 16.0 & 11.7 & 15.7 & 2.6 \\
\hline
\end{tabular}

Note:

1. define 'average ROE\% consistency' as average absolute change by year over 6 years

2. year0 ROE\% performance is not shown but is $15 \%$ for all teams A-G 
Table 4

Industry 10, teams A-G, North America region, wholesale market

Performance metrics averaged over six years and relative to competition.

\begin{tabular}{|c|c|c|c|c|c|c|c|c|}
\hline & $\begin{array}{l}\text { operating } \\
\text { profit } \\
\text { relative to } \\
\text { competition }\end{array}$ & & $\begin{array}{l}\text { prices } \\
\text { relative to } \\
\text { competition }\end{array}$ & & $\begin{array}{l}\text { Operating } \\
\text { costs as \% } \\
\text { revenue } \\
\text { relative to } \\
\text { competition }\end{array}$ & & $\begin{array}{l}\text { annual } \\
\text { volume } \\
\text { sales } \\
\text { growth } \\
\text { relative } \\
\text { competition }\end{array}$ & \\
\hline Team & & comment & & comment & & comment & & comment \\
\hline A & 0.97 & & 0.99 & & 0.97 & & 0.44 & \\
\hline B & 0.85 & & 1.04 & & 1.02 & & 0.51 & \\
\hline $\mathrm{C}$ & 1.13 & $\begin{array}{l}13 \% \\
\text { above } \\
\text { average }\end{array}$ & 1.09 & $\begin{array}{l}9 \% \text { above } \\
\text { average }\end{array}$ & 0.97 & $\begin{array}{l}3 \% \\
\text { below } \\
\text { average }\end{array}$ & 2.62 & $\begin{array}{l}262 \% \\
\text { above } \\
\text { average }\end{array}$ \\
\hline D & 0.87 & & 0.92 & & 1.00 & & -0.25 & \\
\hline $\mathrm{E}$ & 1.95 & $\begin{array}{l}95 \% \\
\text { above } \\
\text { average }\end{array}$ & 1.08 & $\begin{array}{l}8 \% \text { above } \\
\text { average }\end{array}$ & 0.97 & $\begin{array}{l}3 \% \\
\text { below } \\
\text { average }\end{array}$ & 1.81 & $\begin{array}{l}81 \% \\
\text { above } \\
\text { average }\end{array}$ \\
\hline $\mathrm{F}$ & 0.47 & & 0.89 & & 1.04 & & 0.38 & \\
\hline
\end{tabular}




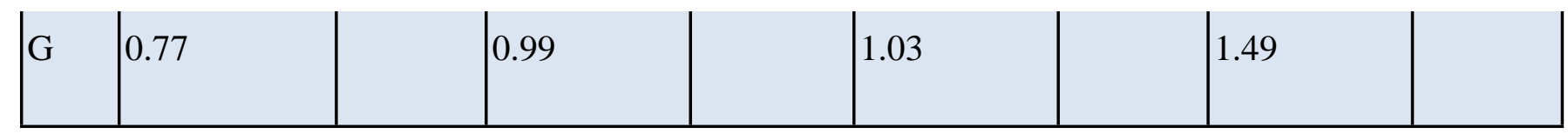

